\title{
The Implementation of Education Management Standards in the School Laboratory State University of Malang for Improving Educational Quality
}

\author{
Ahmad Nurabadi \\ Department of Educational Administration \\ State University of Malang, Indonesia \\ ahmad.nurabadi.fip@um.ac.id
}

\author{
Sucipto \\ Department of Educational Non-formal \\ State University of Malang, Indonesia \\ sucipto.fip@um.ac.id
}

\author{
Juharyanto \\ Department of Educational Administration \\ State University of Malang, Indonesia \\ juharyanto.fip@um.ac.id \\ Imam Gunawan \\ Department of Educational Administration \\ State University of Malang, Indonesia \\ imam.gunawan.fip@um.ac.id
}

\begin{abstract}
This study aims to describe the assessment of the results of the implementation of education management standards through school-based management of the Laboratory of State University of Malang, with reference to the components: (1) curriculum and learning; (2) students; (3) educators and education personnel; (4) financing; (5) infrastructure facilities; (6) school and community relations; and (7) the culture of the school environment. The research method used is quantitative descriptive. Data analysis was carried out using descriptive analysis techniques, namely by determining the frequency and percentage. The results of the study conclude: (1) the implementation of curriculum and learning management is very good quality, (2) the implementation of the management of students includes very good quality; (3) implementation of the management of educators and education personnel including in good quality; (4) implementation of financing management including very good quality; (5) implementation of infrastructure facilities including good quality; (6) implementation of school and community relationship management including good quality; and (7) implementation of school culture and environment including good quality.
\end{abstract}

Keywords: implementation, education management standards, education quality

\section{INTRODUCTION}

Schools in Indonesia vary in the implementation of school-based management, both in quantity and quality, and there are various problems and obstacles to the implementation of school-based management. Therefore, the sustainability of schoolbased management programs needs to be implemented immediately (Kimbrough and Burkett, 1990; Kowalski, 2003; Kummerer and Lynch, 1990).

The sustainability of school-based management programs in Indonesia is mandated by government policy (Kummerer and Lynch, 1990), which is stated in Law Number 20 of 2003 concerning the National Education System, in article 51 paragraph 1 states the management of early childhood education units, basic education and secondary education is carried out based on minimum service standards with the principles of school-based management.

State University of Malang Laboratory School (UM); is an educational institution that seeks to facilitate the implementation of government regulations in the field of education, especially the education standards that have been established, one of which is education management standards. Management of education as stated in Law Number 20 of 2003 concerning the National Education System explains that education management is carried out using a school-based management approach.

The UM Laboratory School, through UPT P2LP UM, is fully aware that as one of the institutions responsible for the management system of education at the university level, especially for schools that are supported (8 schools); it continues to strive to improve the quality of school performance through schoolbased management. School-based management is used as a school management approach to improve the quality of education in schools as a whole with an emphasis on seven components, namely: (1) curriculum and learning; (2) students; (3) educators and education personnel; (4) financing; (5) facilities and infrastructure; (6) school and community relations; and (7) school culture and environment.

\section{METHODS}

This research is a descriptive study that aims to describe a phenomenon as it was at the time the research was conducted, regarding the assessment of attitudes or opinions, understanding of a case within the school organization (Gunawan, 2016a). This study describes the level of implementation of school-based management at the School of UM Laboratory to improve the quality of education.

The population of this study were all principals and teachers in the UM Laboratory School. Data analysis was carried out using descriptive analysis techniques, namely by determining the frequency and percentage (Gunawan, 2013; Gunawan, 2016).

\section{RESULTS}

\section{Curriculum and Learning Components}

Based on the data obtained, the frequency of implementation of school-based management in the curriculum and learning components can be seen in Table 1. Based on Table 1 it is known from 5 respondents, the number of respondents in qualifications: very good as many as 4 respondents 
(80\%); and good as many as 1 respondent $(20 \%)$. So it was concluded that the implementation of school-based management in the curriculum and learning components in the category was very good.

Based on the data obtained, the curriculum and learning components have 10 indicators. Indicators in the implementation of school-based management in the curriculum and learning components have different values. It can be clearly seen in Table 2. Based on Table 2, it is known that the learning process indicator has the highest percentage or average value of 88.41 and an average value of 3.54 . While the indicator of instructional supervision have the lowest percentage or average value of 67.21 and an average value of 2.51 .

Table 1

Implementation of School Based Management Curriculum and Learning Components

\begin{tabular}{|c|l|c|c|c|}
\hline \multirow{2}{*}{ No } & \multicolumn{1}{|c|}{ Classification } & Interval & Frequency & \multirow{2}{*}{ Percentage } \\
\hline 1 & Very good & $34-40$ & 4 & 80 \\
\hline 2 & Good & $26-33$ & 1 & 20 \\
\hline 3 & Enough & $18-25$ & 0 & 0 \\
\hline 4 & Low & $10-17$ & 0 & 0 \\
\hline \multicolumn{2}{|}{ Jumlah } & $\mathbf{5}$ & $\mathbf{1 0 0}$ \\
\hline
\end{tabular}

Table 2

Percentage and Average Value of Curriculum and Learning Components

\begin{tabular}{|c|l|c|c|}
\hline \multicolumn{1}{|c|}{ Percentage and Average Value of Curriculum and Learning Components } \\
\hline \multicolumn{1}{|c|}{ No } & \multicolumn{1}{|c|}{ Indicator } & Percentage & Average \\
\hline 1 & The scope of activities & 85.23 & 3.41 \\
\hline 2 & Learning process & 88.41 & 3.54 \\
\hline 3 & Class management & 74.83 & 2.99 \\
\hline 4 & Learning Resources & 79.07 & 3.16 \\
\hline 5 & Learning outcomes & 78.35 & 2.13 \\
\hline 6 & Assessment of learning outcomes & 73.37 & 2.51 \\
\hline 7 & Instructional supervision & 67.21 & 2.99 \\
\hline 8 & Stages of instructional supervision & 73.93 & 3.01 \\
\hline 9 & The role of parents & 76.07 & 3.12 \\
\hline 10 & Proof of activity & 78.05 & \\
\hline
\end{tabular}

\section{Student Components}

Based on the data obtained, the frequency of the components of students can be seen in Table 3 . Based on Table 3 it is known from 5 respondents, the number of respondents in qualifications: very good as many as 4 respondents $(80 \%)$; and good as many as 1 respondent $(20 \%)$. So it was concluded that the implementation of school-based management in the components of students was in the very good category.
Based on the data obtained, there are 9 indicators for students. Indicators in the implementation of school-based management in the components of students have different values. Clearly, it can be seen in Table 4. Based on Table 4, it is known that the new student admission indicator has the highest percentage or average value of 88.11 and an average value of 3.51. While the indicators of student discipline development have the lowest percentage or average value of 66.62 and an average value of 2.49 .

Table 3

Implementation of Student-Based School Component Management

\begin{tabular}{|c|l|c|c|c|}
\hline \multirow{2}{*}{ No } & \multicolumn{1}{|c|}{ Classification } & Interval & Frequency & \multirow{2}{*}{ Percentage } \\
\hline 1 & Very good & $31-36$ & 4 & 80 \\
\hline 2 & Good & $24-30$ & 1 & 20 \\
\hline 3 & Enough & $17-23$ & 0 & 0 \\
\hline 4 & Low & $09-16$ & 0 & 0 \\
\hline \multicolumn{2}{|r}{ Jumlah } \\
\hline
\end{tabular}

Table 4

Percentage and Mean Value of Student Components

\begin{tabular}{|c|l|c|c|}
\hline No & \multicolumn{1}{|c|}{ Indicator } & Percentage & Average \\
\hline 1 & The scope of activities & 82.23 & 3.32 \\
\hline 2 & Acceptance of new students & 88.11 & 3.51 \\
\hline 3 & New student orientation & 84.13 & 3.45 \\
\hline 4 & Extracurricular activities & 78.07 & 3.02 \\
\hline 5 & Gifted child services & 79.15 & 3.13 \\
\hline 6 & Special services & 73.24 & 2.91 \\
\hline 7 & Student discipline development & 66.62 & 2.99 \\
\hline 8 & Student achievement & 75.98 & 3.11 \\
\hline 9 & Activity books & 79.05 & \\
\hline
\end{tabular}


Components of Educators and Education Personnel

Based on the data obtained, the frequency of the components of educators and education personnel can be seen in Table 5. Based on Table 5, it is known from 5 respondents, the number of respondents in qualifications: very good as many as 3 respondents (60\%); and good as many as 2 respondents $(40 \%)$. So it was concluded that the implementation of school-based management components of educators and education personnel was in the very good category.
Based on the data obtained, the curriculum and learning components have 9 indicators. Indicators in the implementation of management are based on components of educators and education personnel have different values. It can be clearly seen in Table 6 . Based on Table 6, it is known that the indicator of academic qualifications has the highest percentage or average value of 92.35 and an average value of 3.73. While the guidance indicator has the lowest percentage or average value of 65.07 and an average value of 2.41 .

Table 5

Implementation of School-Based Management Components of Educators and Education Personnel

\begin{tabular}{|c|l|c|c|c|}
\hline No & \multicolumn{1}{|c|}{ Classification } & Interval & Frequency & Percentage \\
\hline 1 & Very good & $31-36$ & 3 & 60 \\
\hline 2 & Good & $24-30$ & 2 & 40 \\
\hline 3 & Enough & $17-23$ & 0 & 0 \\
\hline 4 & Low & $09-16$ & 0 & 0 \\
\hline \multicolumn{2}{|r}{ Jumlah } & $\mathbf{5}$ & $\mathbf{1 0 0}$ \\
\hline
\end{tabular}

Table 6

Percentage and Average Value of Components of Educators and Education Personnel

\begin{tabular}{|c|l|c|c|}
\hline No & \multicolumn{1}{|c|}{ Indicator } & Percentage & Average \\
\hline 1 & The scope of activities & 81.45 & 3.22 \\
\hline 2 & Recruitment of educators and education personnel & 89.91 & 3.62 \\
\hline 3 & Development of educators and education personnel & 66.83 & 2.49 \\
\hline 4 & Development of educators and education personnel & 65.07 & 2.41 \\
\hline 5 & Academic qualification & 92.35 & 3.73 \\
\hline 6 & The presence of educators and education personnel & 90.37 & 3.67 \\
\hline 7 & Rules of educators and education personnel & 87.21 & 3.51 \\
\hline 8 & Achievement of educators and education personnel & 75.93 & 3.09 \\
\hline 9 & Activity books for educators and education personnel & 79.01 & 3.14 \\
\hline
\end{tabular}

\section{Financing Components}

Based on the data obtained, the frequency of financing components can be seen in Table 7. Based on Table 7, it is known from 5 respondents, the number of respondents in qualifications: very good as many as 4 respondents $(80 \%)$; and good as many as 1 respondent $(20 \%)$. So it was concluded that the implementation of school-based management in the financing component was in the very good category.
Based on the data obtained, the financing component has 7 indicators. Indicators in the implementation of school-based management in financing components have different values. Clearly, it can be seen in Table 8 . Based on Table 8 , it is known that the principle indicator of financing preparation has the highest percentage or average value of 89.31 and an average value of 3.57 . While the annual work plan indicator has the lowest percentage or average value of 72.31 and an average value of 2.91 .

Table 7

Implementation of School Based Management Financing Components

\begin{tabular}{|c|l|c|c|c|}
\hline \multirow{2}{*}{ No } & \multicolumn{1}{|c|}{ Classification } & Interval & Frequency & \multirow{2}{*}{ Percentage } \\
\hline 1 & Very good & $24-28$ & 4 & 80 \\
\hline 2 & Good & $18-23$ & 1 & 20 \\
\hline 3 & Enough & $13-17$ & 0 & 0 \\
\hline 4 & Low & $07-12$ & 0 & 0 \\
\hline \multicolumn{2}{|c|}{ Jumlah } & $\mathbf{5}$ & $\mathbf{1 0 0}$ \\
\hline
\end{tabular}

Table 8

Percentage and Mean Value of Financing Components

\begin{tabular}{|c|l|c|c|}
\hline \multirow{2}{*}{ No } & \multicolumn{1}{|c|}{ Indicator } & Percentage & Average \\
\hline 1 & The scope of activities & 87.93 & 3.52 \\
\hline 2 & Principles of preparation & 89.31 & 3.57 \\
\hline 3 & School work plan & 74.83 & 2.99 \\
\hline 4 & Extracting financing sources & 79.17 & 3.17 \\
\hline 5 & The annual work plan & 72.31 & 2.91 \\
\hline 6 & Management principle & 78.37 & 3.18 \\
\hline 7 & Activity books & 85.05 & 3.42 \\
\hline
\end{tabular}




\section{Infrastructure Facility Components}

Based on the data obtained, the frequency of the infrastructure components can be seen in Table 9. Based on Table 9, it is known from 5 respondents, the number of respondents in qualifications: very good as many as 3 respondents (60\%); and good as many as 2 respondents $(40 \%)$. So it was concluded that the implementation of school-based management in the components of school facilities and infrastructure was in the very good category.
Based on the data obtained, there are 8 indicators of school infrastructure and facilities. Indicators in the implementation of school-based management in the infrastructure component have different values. It can be clearly seen in Table 10 . Based on Table 10, it is known that the indicator of school location has the highest percentage or average value of 92.83 and an average value of 3.69. While the classroom setting indicator has the lowest percentage or average value of 75.37 and an average value of 3.08.

Table 9

Implementation of School-Based Management of Facilities and Infrastructure Components

\begin{tabular}{|c|l|c|c|c|}
\hline No & \multicolumn{1}{|c|}{ Classification } & Interval & Frequency & Percentage \\
\hline 1 & Very good & $26-32$ & 3 & 60 \\
\hline 2 & Good & $21-25$ & 2 & 40 \\
\hline 3 & Enough & $14-20$ & 0 & 0 \\
\hline 4 & Low Jumlah & $08-13$ & 0 & 0 \\
\hline \multicolumn{2}{|r|}{} & $\mathbf{5}$ & $\mathbf{1 0 0}$ \\
\hline
\end{tabular}

Table 10

Percentage and Average Value of Facilities and Infrastructure Components

\begin{tabular}{|c|l|c|c|}
\hline \multicolumn{1}{|c|}{ Indicator } & \multicolumn{1}{|c|}{ Percentage and Average Value of Facilities and Infrastructure Components } \\
\hline 1 & \multicolumn{1}{|c|}{ No } & Percentage & Average \\
\hline 2 & School infrastructure & 81.23 & 3.24 \\
\hline 3 & School location & 88.41 & 3.54 \\
\hline 4 & Facilities maintenance & 92.83 & 3.16 \\
\hline 5 & Distribution of infrastructure & 79.07 & 3.13 \\
\hline 6 & Classroom settings & 78.35 & 3.08 \\
\hline 7 & Removal of infrastructure & 75.37 & 3.18 \\
\hline 8 & Proof of activity & 80.21 & 3.32 \\
\hline
\end{tabular}

\section{Components of School and Community Relations}

Based on the data obtained, the frequency of the components of school and community relations can be seen in Table 11. Based on Table 11, it is known from 5 respondents, the number of respondents in qualifications: very good as many as 1 respondent (20\%); good as many as 2 respondents (40\%); and enough as many as 2 respondents $(40 \%)$. So it was concluded that the implementation of school-based management in the school and community relations component was in good category.
Based on the data obtained, there are 10 indicators of school and community relations. Indicators in the implementation of school-based management components of school and community relations have different values. It can be clearly seen in Table 12. Based on Table 12, it is known that the indicator of the scope of public relations has the highest percentage or average value of 85.23 and an average value of 3.41. While the school committee role indicator has the lowest percentage or average value of 66.11 and an average value of 2.43 .

Table 11

Implementation of School-Based Management Components of School and Community Relations

\begin{tabular}{|c|c|c|c|c|}
\hline No & Classification & Interval & Frequency & Percentage \\
\hline 1 & Very good & $34-40$ & 1 & 20 \\
\hline 2 & Good & $26-33$ & 2 & 40 \\
\hline 3 & Enough & $18-25$ & 2 & 40 \\
\hline 4 & Low & $10-17$ & 0 & 0 \\
\hline \multicolumn{3}{|c|}{ Jumlah } & 5 & 100 \\
\hline
\end{tabular}

Table 12

Percentage and Average Value of School and Community Relations Components

\begin{tabular}{|c|l|c|c|}
\hline No & \multicolumn{1}{|c|}{ Indicator } & Percentage & Average \\
\hline 1 & The scope of activities & 85.23 & 3.41 \\
\hline 2 & Target of cooperation & 82.42 & 3.24 \\
\hline 3 & Implementation of public relations duties & 74.83 & 2.99 \\
\hline 4 & PR activities & 79.07 & 3.16 \\
\hline 5 & Public relations techniques & 78.35 & 3.13 \\
\hline 6 & Communication methods & 73.37 & 2.93 \\
\hline 7 & The role of the school committee & 66.11 & 2.43 \\
\hline 8 & Empowering the class community & 71.33 & 2.86 \\
\hline 9 & Types of community participation & 72.09 & 2.91 \\
\hline 10 & Proof of activity & 76.26 & 3.04 \\
\hline
\end{tabular}




\section{Components of School Environment Culture}

Based on the data obtained, the frequency of the school's cultural and environmental components can be seen in Table 13. Based on Table 13, it is known from 5 respondents, the number of respondents in qualifications: very good as many as 2 respondents (40\%); and good as many as 3 respondents $(60 \%)$. So it can be concluded that the implementation of schoolbased management in the cultural and environmental components of the school is in the good category.

Based on the data obtained, the cultural and environmental components of the school are 9 indicators. Indicators in the implementation of schoolbased management in the cultural and environmental components of schools have different values. It can be clearly seen in Table 14. Based on Table 14, it is known that the scope of the activity indicator has the highest percentage or average value of 81.23 and an average value of 3.23 . While the indicators of saving and maintaining the culture of the school environment has the lowest percentage or average value of 67.42 and an average value of 2.53 .

Table 13

Implementation of School-Based Management of the Cultural Components of the School Structure

\begin{tabular}{|c|l|c|c|c|}
\hline No & \multicolumn{1}{|c|}{ Classification } & Interval & Frequency & Percentage \\
\hline 1 & Very good & $30-36$ & 2 & 40 \\
\hline 2 & Good & $23-29$ & 3 & 60 \\
\hline 3 & Enough & $16-22$ & 0 & 0 \\
\hline 4 & Low Jumlah & $10-17$ & 0 & 0 \\
\hline \multicolumn{2}{|r|}{} & $\mathbf{5}$ & $\mathbf{1 0 0}$ \\
\hline
\end{tabular}

Table 14

Percentage and Average Value of Cultural Components and School Circles

\begin{tabular}{|c|l|c|c|}
\hline No & \multicolumn{1}{|c|}{ Indicator } & Percentage & Average \\
\hline 1 & The scope of activities & 81.23 & 3.23 \\
\hline 2 & Program socialization & 80.41 & 3.17 \\
\hline 3 & Exemplary types & 76.83 & 3.09 \\
\hline 4 & Cultural seeding & 79.02 & 3.16 \\
\hline 5 & Cultural development & 78.36 & 3.13 \\
\hline 6 & Environmental development & 73.31 & 2.92 \\
\hline 7 & To protect and maintain the culture of the school environment & 67.42 & 2.53 \\
\hline 8 & Environmental creation & 73.81 & 2.92 \\
\hline 9 & Use of the environment as a learning resource & 76.34 & 3.04 \\
\hline
\end{tabular}

\section{DISCUSSION}

This research reveals and reviews the implementation of education management in accordance with government and university policies. Based on the description of the data, it is known that educational institutions, especially schools need evaluation and standardization in the implementation of education management. Evaluation is important to be carried out to support and at the same time become a foothold in making institutional development plans in the future (Koontz, 1984; Law and Glover, 2000; Nason, 1977).

Decentralization of education management provides an opportunity for related parties to develop an education system that is better suited to the needs of each region. Education management in the past, carried out centrally and the authority of local governments and schools was very limited. Submission of responsibilities and resources to schools provides them with opportunities to identify and meet their own needs (Owens, 1991; Robbins, 1984).

In addition, the submission of these responsibilities will motivate schools and communities to develop things that were once considered not their business. With more decisions taken at the school level, the use of resources including learning funds is expected to be more in line with the needs of schools and local students. Schools in the framework of strengthening and developing the implementation of school-based management are given the authority to make decisions. The decision taken must be in accordance with the interests of the school community, students, and the community. So that programs run by schools are more relevant to needs, accountable and transparent (Owens, 1991).

The community is obliged to provide resource support in the delivery of education (Rowland and Ferris, 1982; Sergiovanni, 1991). Community participation in education includes: the participation of individuals, groups, families, professional organizations, entrepreneurs, and community organizations in the implementation and quality control of educational services. The form of community participation can be in the form of sources, implementers, and users of educational outcomes.

In an effort to continue and develop a schoolbased management program, the Strategic Plan of Ministry of National Education's 2010-2014, mandates that by the end of $2014,90 \%$ of schools in Indonesia have implemented school-based management well. Therefore, strategic steps to increase quantity and quality to implement school-based management properly need to be prepared and implemented immediately (Stolp and Smith, 1994; Kummerer and Lynch, 1990). The principles of school-based management are: (1) independence; (2) justice; (3) 
openness; (4) partnership; (5) participatory; (6) efficiency; and (7) accountability.

\section{CONCLUSION}

Based on the results of the study, the conclusions of this study are: (1) the implementation of curriculum and learning management is very good quality, (2) the implementation of the management of students is of very good quality; (3) implementation of the management of educators and education personnel including in good quality; (4) implementation of financing management including very good quality; (5) implementation of infrastructure facilities including good quality; (6) implementation of school and community relationship management including good quality; and (7) implementation of school culture and environment including good quality.

\section{REFERENCES}

[1] Gunawan, I. 2013. Statistika untuk Kependidikan Sekolah Dasar. Yogyakarta: Penerbit Ombak.

[2] Gunawan, I. 2016a. Metode Penelitian Kuantitatif. Retrieved June 7, 2017, from http://fip.um.ac.id/wpcontent/uploads/2015/12/2_Metpen-Kuantitatif.pdf.

[3] Gunawan, I. 2016a. Pengantar Statistika Inferensial. Jakarta: Rajawali Pers.

[4] Kimbrough, R. B., and Burkett, C. W. 1990. The Principalship: Concepts and Practices. New Jersey: Prentice Hall, Inc.

[5] Koontz, H. 1984. Management. London: McGraw-Hill International Book Company.

[6] Kowalski, T. J. 2003. Contemporary School Administration. Boston: Pearson Education, Inc.

[7] Kummerer, F. N. D., and Lynch, P. 1990. Educational Policy and Planning Project: A Review of Teacher Education Issues in Indonesia. Jakarta: Center for Informatics Office of Educational and Cultural Research and Development.

[8] Law Number 20 of 2003 concerning the National Education System. 2004. Jakarta: Ministry of National Education.

[9] Law, S., and Glover, D. 2000. Educational Leadership and Learning: Practice, Policy, and Research. Philadelphia: Open University Press.

[10] Nason, L. J. 1977. Help Your Child Secced in School. New York: Coner Stone Library.

[11] Owens, R. G. 1991. Organizational Behavior Education. Boston: Allyn and Bacon, Inc.

[12] Robbins, S. P. 1984. Management: Concept and Practices. Englewood Cliffs: Prentice Hall, Inc.

[13] Rowland, K. M., and Ferris, G. R. 1982. Personnel Management. Boston: Allyn and Bacon.

[14] Sergiovanni, T. J. 1991. The Principalship: A Reflective Practice Perspective. Boston: Allyn and Bacon.

[15] Stolp, S., and Smith, S. C. 1994. School Culture and Climate: The Role of the Leader. OSSC Bulletin, Eugene Oregon School Study Council, January, p. 57.

[16] The Strategic Plan of Ministry of National Education's 2010-2014. 2010. Jakarta: Kementerian Pendidikan Nasional. 